\title{
A Dynamic Study of Racial Inequality in Home Equity during the Housing Bubble
}

\author{
Wenqian Dai ${ }^{1} \&$ Ying Yang $^{2}$ \\ ${ }^{1}$ Department of Anthropology and Sociology, University of South Dakota, United States \\ ${ }^{2}$ Department of Sociology and Anthropology, Shippensburg University of Pennsylvania, United States \\ Correspondence: Wenqian Dai, Department of Anthropology and Sociology, University of South Dakota, United States
}

Received: July 2, 2014

doi:10.11114/ijsss.v2i4.457

\begin{abstract}
From 2001 to 2005 the American housing market witnessed a housing bubble with rising housing prices and home ownership rates. Home equity that constitutes a large share of net worth for most families increases also during this housing bubble. This paper examines the degree to which the overall increase in housing prices and in home ownership rates affected the wealth accumulation of whites and various minority groups. Using data from the American Housing Survey of 2001 and 2005, we find that the distance between white and Black homeowners in home equity is amplified between 2001 and 2005, but the advantage of white owners over Hispanic owners disappears once other factors are held constant. Asians benefit dramatically from the housing bubble, their home equity surpasses that of whites after other variables are controlled. These findings further broaden our understanding about racial stratification in wealth in American society.
\end{abstract}

Keywords: assimilation perspective, housing bubble, institutional discrimination in housing market, racial inequality in home equity, racial wealth stratification, stratification model.

\section{Introduction}

The real estate market in the United States experienced a housing bubble from 2001 to 2005. During this spell of time, both the homeownership rate and housing values increased. The U.S. Bureau of the Census reports that the national median price of occupied housing units increased by $24 \%$, from $\$ 135,626$ in 2000 to $\$ 167,500$ in $2005^{1}$. This boom brought American homeowners an increase in their home equity, that is, the market value of a home, exclusive of mortgage debt. The U.S. Federal Reserve reports a $15 \%$ increase in the national median value of primary residence equity, from $\$ 144,530$ in 2001 to $\$ 165,440$ in 2004 . Home equity is one of the primary elements of family net worth. Its increase not only helps American families accumulate more wealth but also changes the structure of family assets. The U.S. Federal Reserve reports that the share of all residential properties' equity increased from $32 \%$ of family net worth in 2001 to $39 \%$ in 2004 .

Wealth inequality between racial and ethnic groups has drawn the interest of sociologists (Alba \& Logan 1992; Oliver \& Shapiro 1995; Flippen, 2001a, 2001b, 2004; Shapiro 2004; Krivo \& Kaufman 2004). These studies suggest that research into wealth accumulation is important for revealing how a racially stratified social structure perpetuates racial and ethnic inequality in the United States. Housing is the largest single asset among the vast majority of American households and it also provides tax and inflation protection. The accumulation of housing wealth reflects broader processes of social stratification. Housing inequality contributes to racial and ethnic inequality in wealth accumulation and reinforces racial stratification. Racial and ethnic housing inequality has been examined in many studies. Racial and ethnic minorities have been found to be disadvantaged in acquiring homeownership and in financial returns from the investment in houses, compared to whites (Charles 2001; Conley 1999; Emerson, Chai and Yancey 2001; Krivo 1986; Oliver \& Shapiro 1995; Wilson \& Hammer 2001; Flippen 2004).

The United States is undergoing a demographic change in racial and ethnic composition. Hispanic and Asian populations are growing rapidly and a large part of these two groups are immigrants. The new wave of immigrants is

\footnotetext{
${ }^{1}$ All amounts of dollars reported in this chapter are converted to 2005 dollars by using Congressional Budget Office estimates of inflation conversion factors.
} 
mainly composed of Hispanics and Asians. The 2000 Census shows that Hispanics have increased by $58 \%$ and Asians have increased by $76 \%$ since 1990. The rapid growth of the Hispanic and Asian populations suggests the potential for change in residential patterns. Thus dichotomous white-Black studies of housing inequality are becoming out-dated. Hispanics and Asians, therefore, should receive more attention in exploration of racial and ethnic inequality in housing wealth.

This paper is intended to study the impact of this "housing bubble" on the racial and ethnic differences in home equity. Given that wealth accumulation is such an overtime process, a longitudinal study will enable a better view of the persistence and perpetuation of the racial and ethnic disparities in home equity. A study of dynamic interactions between the housing market and racial stratification is going to provide a better view of the causes and consequences of racial inequality in wealth. In this paper, we use the national samples from 2001 and 2005 of the American Housing Survey (AHS) to examine the impact of the recent housing bubble on the ethnic gaps in home equity. Given the fact that wealth is accumulated over time, the AHS longitudinal survey of housing units offers a view of change during the housing boom of racial disparities in wealth accumulation. The 2001 and 2005 AHS allow me to conduct a longitudinal study of ethnic housing inequality in the United States from 2001 to 2005.

\section{Theoretical Backgrounds}

Research on housing inequality, including homeownership, residential mobility and housing equity has generally worked with the microeconomic explanations, in particular the life-cycle thesis of consumer behavior. Households choose to purchase according to their needs, preferences and available financial resources. People accumulate their assets over a life course based upon their earlier and current economic sources until retirement. Age, marital status, the number of children and income, accordingly, are identified as the explanatory factors for housing inequality (Alba \& Logan, 1992; Flippen, 2004; Krivo \& Kaufman, 2004; Oliver \& Shapiro, 1995; Shapiro, 2004).

The classic assimilation thesis attributes the residential and housing disparities among racial groups to compositional differences, acculturation and human capital endowments. Homeownership is a likely necessary step for immigrants to achieve upward residential mobility. Homeownership is also a form of assimilation that represents a long-term commitment to American society and a working knowledge of housing markets in the U.S. Minority groups' lower socioeconomic status and new immigrants' limited knowledge of the housing market, and cultural distinctiveness, could explain their disadvantages in residential mobility and housing wealth accumulation. Variables of human capital, acculturation and immigration status, such as income, education, English-proficiency, duration of residence in U.S., citizenship and native birth are controlled to understand the racial differences in residential mobility, homeownership and housing equity (Alba et al., 1999; Alba, Logan, and Stults, 2000; Alba \& Logan 1991, 1992; Flippen, 2004; Krivo, 1995; Krivo \& Kaufman, 2004; Logan, Alba, and Leung 1996; Logan et al., 1996; Logan, Alba, and Zhang, 2002; Logan, Stults, and Farley, 2004; Massey, 1985; Massey and Denton, 1992a, 1992b; South et al., 2005).

The stratification model points out the consistent racial disparity when controls for other factors are taken into account and explain disparities in terms of the racial segregation of the housing market. Racial group membership itself is a determinant of housing inequality. Unfavorable mortgage and other financial lending practices also limit the ability of minority groups to acquire homeownership and to accrue home equity. Minorities are discriminated against in the housing market and largely excluded from desirable communities. The strength of other factors, in addition to the direct effect of race, might differentiate between whites and minority groups. Race, financial characteristics and contextual variables, such as homeownership rates in the central city and the suburb and the population composition in a metropolis are taken into account by the stratification perspective. The effects of other control variables are also compared among racial groups (Alba \& Logan, 1992; Krivo, 1986; Megbolugbe and Cho, 1996; Rosenbaum, 1996; Ross \& Yinger, 2002).

Even after racially based mortgage became illegal, certain institutional mechanisms and discriminatory lending acts still impede members of disadvantaged minority groups to attain residential parity with whites, such as exclusionary zoning and unequal access to mortgages. Racial discrimination existed at each step in the complex financial chain from mortgage application to foreclosure (Bond \& Williams, 2007; Rugh \& Massey, 2010; Williams, Nesiba, and McConell, 2005). Blacks and Hispanics are more disadvantaged in the process of applying for mortgages and refinancing their houses compared to whites. The needy minority group members in segregated neighborhoods become the targets of predatory subprime lending (Avery, Brevoort, and Canner, 2008; Been, Ellen, and Madar, 2009; Farley, 1996; Massy and Denton, 1993; Stuart, 2003; Williams, Nesiba, and McConnell, 2005).

Because of discriminatory lending, it costs members of racial minority groups more to pursue homeownership and reach suburbs and they may be less able to translate their needs and preferences associated with household composition into residential mobility. Blacks and Hispanics are turned down more often than comparable whites for home financing (Holloway \& Wyly, 2001; Myers \& Chan, 1995; Oliver \& Shapiro, 1995; Rosenbaum \& Friedman, 2001; Turner, 1992; 
Yinger ,1995). The strength of other factors, in addition to the direct effect of race, is different between whites and minority groups. Compared with their effects on whites, the impact of socioeconomic variables is stronger and the impact of the household composition variables is weaker on minority group members' pursuit of suburban residence and better neighborhoods (Alba \& Logan, 1992; Krivo, 1986; Megbolugbe \& Cho, 1996; Rosenbaum, 1996; Ross \& Yinger, 2002).

Blacks and Hispanics have experienced a high level of residential segregation, in addition. Blacks are heavily segregated in low-income communities (Charles, 2001; Emerson, Chai, and Yancey, 2001; Massey \& Denton, 1993; Rugh \& Massey, 2010; Wilson \& Hammer, 2001; Flippen, 2004). The practice of redlining denies service or increases the cost of service, such as banking and financing, to the residents in certain often minority dominated neighborhoods. Massey and Denton (1993: 106) concludes that "blacks and racially mixed neighborhoods receive less credit, fewer federally insured loans, fewer home improvement loans, and less total mortgage money than socioeconomically comparative white neighborhoods."

\section{Method}

\subsection{Data}

The 2001 and 2005 American Housing Survey (AHS) were used to analyze the racial-ethnic gaps in home equity. AHS is a longitudinal survey of housing units and this national sample survey has been conducted every other year since 1985. The sampled housing occupants provide their basic demographic information, such as age, race and ethnicity and income, and the information on housing characteristics and costs, such as mortgage and down payments. The 2001 AHS included 42, 487 occupied housing units and 43,360 units were sampled by the 2005 AHS.

This paper only studied the residents who claimed to own a permanent housing unit since home equity is a concept limited to house owners. The residents of a mobile home, nonhomeowners and those with missing data for equity were excluded from the analysis here. There have been considerable researches about the homeownership inequality between white and the racial and ethnic minority groups. Thus here we put our emphasis on how home equity has been accumulated unequally for those homeowners from different racial and ethnic groups.

\subsection{Regression Model}

OLS regression models are conducted to explore the effect of race on home equity for homeowners only. Some homeowners had negative equity and some had equity of 0 . General and group-specific OLS models are conducted to analyze the racial disparities in home equity among homeowners. All of these regression models include predictor variables to control race/ethnicity as well as household composition, assimilation, socioeconomic status, geographic location and financial and mortgage characteristics. All regression models using the data from AHS are estimated for 2001 and 2005 separately. The comparison of these two years can infer the impact of the recent booming real estate market on changes in racial inequality in homeownership, housing value and home equity.

\subsection{Variables}

The appendix presents the operationalization of the variables. Home equity, the dependent variable, is measured as the self-estimated market value of an owned home minus the total amount of mortgages owned on the property (in $\$ 10,000)^{2}$. The regression coefficients can then directly show the changes in the amount of home equity (in $\$ 10,000$ ) with the changes in the predictor variables.

Race is measured with dummy variables: whites, Blacks, Hispanics and Asians and whites are the reference group using the respondents' self-identification. Only the householders and the spouses, if there was one, who claimed to be in a single racial group are taken into account. Those who identified themselves as a member of multi-racial groups are excluded. For married couples, intermarriage is taken into account. If one of a couple is white, then the household is classified to be white. A Black-Hispanic or Black-Asian household is classified to be Black. A Hispanic-Asian household is classified to be Hispanic. Intermarriage is an indicator of assimilation.

Household composition characteristics are controlled, including age, householder's gender, marital status and the number of children in the household under 18 years old. Marital status is a dummy variable to differentiate the currently married couples from those who are not married, no matter whether the spouse is present or absent. Age is the maximum of the householder's or the spouse's values.

Socioeconomic status is measured by educational degree and household yearly income (in $\$ 10,000$ ). Educational degree is the maximum of the householder's or the spouse's values. It is measured with a set of dummy variables comparing less than high school certificate, high school degree, some college education, college degree and post college education.

\footnotetext{
${ }^{2}$ AHS asks values of the housing units occupied by owners only. Housing values are self-reported by owners or are estimated by AHS survey representatives in accordance with the sales advertisement if owners are absent.
} 
Some research has demonstrated the nonlinear effect of income on wealth, particularly housing wealth (Flippen, 2001a). Homeownership requires a certain minimum income, which creates an income threshold effect on homeownership at the lower end. The effect of income on housing wealth will decrease beyond a certain level due to diminishing marginal returns. In this study, the natural $\log$ of household yearly income $(\$ 10,000)$ is used as a regressor because of this probable nonlinearity.

Immigration status is used as indicator of assimilation and includes dummy variables for native born U.S. citizens, naturalized citizens and non-U.S. citizens. A married couple will be categorized into the non-U.S. citizen group only if neither is an U.S. citizen. As discussed by Krivo and Kaufman (2004), the presence of a U.S. citizen spouse will overcomes the difficulty of language and information barriers.

Five financial factors that are associated with the greater accumulation of equity are taken into account: prior homeownership, making a down-payment, the mortgage interest rate and controls for variable rate mortgages and FHA/VA/FHAM financing. The dummy indicator of prior ownership measures whether a household owned another housing unit before their current one. Prior ownership indicates the possible equity accumulation from the prior housing unit. The down payment measure is whether or not a household paid a down payment at the time of purchase. Many households made no down payment and this affects home equity accumulation and the interest rate of the mortgage. Making no down payment usually results in a higher interest rate than a traditional mortgage. This study includes dummy variables for variable interest rate mortgages (ARM) and FHA, VA or FHAM financing, both of which will reduce equity. Making no down payment and variable interest rate mortgages (ARM), in addition, increase the risk of foreclosure.

Two indicators are used to control the geographic variation in housing prices and home equity: metropolitan status and region. Four census regions are used in this research: Northeast, Midwest, South and West. Housing appreciation varies by regions. The real estate markets in the Northeast and West were extremely hot from 2001 to 2005. Location is measured with dummy variables for central city, suburb and exurb. Houses in suburban areas have been more likely to appreciate than those in the central city and exurbs. Two other variables are controlled also to address housing appreciation: condominium ownership and length of residence. Length of residence measured in years controls the effect of time on home equity accumulation.

\section{Findings}

\subsection{Descriptive Statistics}

Table 1 presents the distribution of homeownership, housing values and equity by structural type and race from the AHS data in 2001 and 2005. The statistical significance of the differences between percentages or means is tested and all such differences reported in this part of the text are significant. Significance of the difference between medians is not tested. The AHS surveyed 55,086 housing units in 2001 and 59,581 housing units in 2005, including all types of housing units. This study analyzes permanent housing units only. Ninety-two percent of all surveyed units in 2001 and $91 \%$ of housing units surveyed in 2005 were permanent units. Among these permanent units, $55 \%$ were occupied by owners in 2001. In 2005, the comparable figure was 59\%.

The median value of permanent units was $\$ 137,875$ in 2001 and $\$ 170,000$ in $2005^{3}$. There were 29,063 white (76\%), 4,393 Black (12\%), 1,153 Asian (3\%) and 3,453 Hispanic (9\%) households in 2001. There were 29,516 white (75\%), 4,439 Black (11\%), 1,239 Asian (3\%) and 4,050 Hispanic (10\%) households in 2005. In both years, Asians were less likely to own a mobile home than the other racial groups.

Whites have a higher homeownership rate than the three minority groups (74\% in 2001 and $75 \%$ in 2005); while Hispanics have the lowest homeownership rate (44\% in 2001 and $46 \%$ in 2005). The home ownership rate of Blacks (49\% in 2001 and $48 \%$ in 2005) is slightly higher than that of Hispanics. Asians have a rate higher than Blacks and Hispanics but lower than whites (53\% in 2001 and 58\% in 2005). The advantage of whites over other groups is statistically significant in both years. The ownership rates of whites and Asians' increase significantly from 2001 to 2005 whereas the ownership rates of Blacks and Hispanics do not change significantly ${ }^{4}$.

\footnotetext{
${ }^{3}$ All amounts of dollars reported in this part (6.1) are converted to 2005 dollars by using Congressional Budget Office estimates of inflation conversion factors.

${ }^{4}$ Significance of the difference between percentages is accessed with a t-test in this part (6.1). Differences between percentages reported in this part are all statistically significant.
}

$$
t^{*}=\frac{\hat{p_{1}}-\hat{p_{2}}}{\sqrt{\frac{\hat{p_{1}}\left(1-\hat{p_{1}}\right)}{N_{1}}+\frac{\hat{p_{2}}\left(1-\hat{p_{2}}\right)}{N_{2}}}}
$$


The median housing value of Asians is higher than that of the other groups ${ }^{5}$. Blacks have the lowest median housing value in both years. White home owners' median housing value is higher than that of Hispanics in 2001 but a bit lower in 2005. All four groups' median housing value increases from 2001 to 2005. Asians show the highest increasing rate and Hispanics are the second. The increasing rates for whites and Blacks are similar. The racial differences in home equity show a similar pattern except the advantage of whites over Hispanics in both years. Asians and Hispanics experience the fastest increase in median home equity. Whites' increasing rate is higher than Blacks but lower than Asians and Hispanics.

Table 1. Descriptive Statistics of AHS Data

\begin{tabular}{|c|c|c|c|c|c|c|c|c|}
\hline \multirow[t]{2}{*}{ Homeowners } & \multicolumn{4}{|c|}{2001} & \multicolumn{4}{|c|}{2005} \\
\hline & White & Black & Asian & Hispanic & White & Black & Asian & Hispanic \\
\hline Number of Owners & 21795 & 2137 & 607 & 1531 & 22067 & 2143 & 724 & 1875 \\
\hline \multicolumn{9}{|c|}{ Household Composition Characteristics } \\
\hline Married (\%) & 66.74 & 45.77 & 74.96 & 64.99 & 65.70 & 43.96 & 74.72 & 65.13 \\
\hline Male-Headed (\%) & 65.39 & 48.10 & 70.35 & 64.01 & 62.00 & 46.43 & 68.23 & 59.68 \\
\hline Mean Age & 54 & 54 & 48 & 48 & 54 & 54 & 48 & 48 \\
\hline Senior $(\%)$ & 27.31 & 26.63 & 12.30 & 16.26 & 26.97 & 25.06 & 12.85 & 15.95 \\
\hline $\begin{array}{l}\text { Number of } \\
\text { Children }\end{array}$ & 0.6 & 0.8 & 0.9 & 1.2 & 0.6 & 0.7 & 0.9 & 1.2 \\
\hline \multicolumn{9}{|c|}{ Socioeconomic Status } \\
\hline $\begin{array}{l}\text { Median Household } \\
\text { Income }\end{array}$ & 6.0 & 4.2 & 7.7 & 5.0 & 6.0 & 4.2 & 7.7 & 4.7 \\
\hline $\begin{array}{l}\text { Below High } \\
\text { School }(\%)\end{array}$ & 8.78 & 20.73 & 8.07 & 33.77 & 6.90 & 17.08 & 7.32 & 31.63 \\
\hline $\begin{array}{l}\text { College Degree } \\
(\%)\end{array}$ & 37.59 & 26.02 & 59.47 & 18.16 & 41.56 & 27.53 & 63.26 & 20.27 \\
\hline \multicolumn{9}{|l|}{ Immigration (\%) } \\
\hline Naturalized & 1.96 & 3.32 & 56.51 & 23.51 & 2.07 & 4.53 & 59.25 & 22.61 \\
\hline Non-Citizen & 0.67 & 1.26 & 16.14 & 16.39 & 0.75 & 1.68 & 15.61 & 19.89 \\
\hline \multicolumn{9}{|c|}{ Geographic Characteristics (\%) } \\
\hline Northeast & 20.29 & 14.41 & 18.45 & 10.12 & 20.24 & 13.39 & 20.86 & 10.99 \\
\hline Midwest & 28.68 & 19.19 & 10.87 & 9.47 & 28.57 & 18.01 & 12.29 & 9.28 \\
\hline South & 33.13 & 58.68 & 18.12 & 40.63 & 33.25 & 61.50 & 20.30 & 39.84 \\
\hline West & 17.91 & 7.72 & 52.55 & 39.78 & 17.94 & 7.09 & 46.82 & 39.89 \\
\hline Central City & 19.72 & 46.37 & 35.26 & 41.35 & 19.38 & 43.86 & 33.70 & 39.73 \\
\hline Suburb & 54.67 & 37.86 & 62.77 & 49.05 & 53.79 & 39.43 & 61.19 & 48.27 \\
\hline Exurb & 25.61 & 15.77 & 1.98 & 9.60 & 26.83 & 16.71 & 5.11 & 12.00 \\
\hline
\end{tabular}

Note: Only homeowners in permanent housing units are included in this part. Median household income is measured in $\$ 10,000$. Median household income in 2001 is converted to dollar 2005 by using Congressional Budget Office estimates of inflation conversion factors.

\footnotetext{
${ }^{5}$ Significance of the difference between medians is not tested in this paper.
} 
Table 1. Descriptive Statistics of AHS Data (continued)

\begin{tabular}{lrrrrrrrr}
\hline Homeowners & \multicolumn{3}{c}{2001} & & \multicolumn{2}{c}{2005} \\
& White & Black & Asian & Hispanic & White & Black & Asian & Hispanic \\
\hline $\begin{array}{l}\text { Financial Characteristics (\%) } \\
\text { Prior Owner }\end{array}$ & 59.78 & 30.98 & 44.81 & 35.86 & 61.54 & 31.31 & 49.31 & 38.61 \\
Down & & & & & & & & \\
Payment & 87.49 & 80.35 & 92.26 & 89.42 & 87.35 & 80.31 & 91.16 & 86.40 \\
Mean Interest Rate & 7.16 & 7.68 & 6.99 & 7.46 & 5.63 & 6.29 & 5.38 & 5.87 \\
ARM & 45.66 & 48.10 & 29.98 & 39.11 & 43.32 & 46.43 & 32.87 & 36.91 \\
FHA/VA & & & & & & & & \\
/FHAM & 10.76 & 22.09 & 9.72 & 23.84 & 8.16 & 17.64 & 5.66 & 14.03 \\
$\begin{array}{l}\text { Other Factors } \\
\text { Mean Years of Residence }\end{array}$ & 15 & 16 & 9 & 10 & 15 & 16 & 9 & 10 \\
Condominium Owner (\%) & 5.17 & 3.37 & 10.21 & 6.79 & 5.67 & 4.39 & 10.36 & 6.61 \\
\hline
\end{tabular}

4.2 General OLS Regression Models of Home Equity

An important source of wealth is the equity realized by home owners from their houses. OLS regression models are used to predict home equity in this part of the dissertation. In each year, home owners of all four racial groups are pooled into a general OLS regression model and a group-specific OLS regression model is estimated for each racial group's owners. Only home equity of permanent unit owners is analyzed. Analysis of racial inequality in home equity will help us to understand how racial groups differentially realize wealth accumulation from their investment in real estates. Cross group comparisons in each year are tested for their significance ${ }^{6}$. Only significant differences are reported in the text. Across time comparisons discussed in this part should be treated as descriptive because their statistical significance is not accessed.

Home owners show a racially differentiated pattern of acquiring home equity. Blacks and Hispanics accumulate less equity from their homes than do whites. Asians accrue more home equity than other racial groups. In 2005, Blacks' home equity on average is $\$ 14,800$ less than that of whites, when other variables are controlled. The gap between whites and Hispanics is $\$ 16,700$ in 2001. The advantages of Asians over whites on acquisition of home equity in 2001 and 2005 are $\$ 18,400$ and $\$ 23,000$. The racial disparity in home equity between whites and two minority groups, Blacks and Hispanics, is consistent with the stratification perspective.

The gap between whites and Blacks in home equity widens from 2001 to 2005. Whites and Blacks do not significantly differ in home equity in 2001 and Blacks show a disadvantage in 2005. The disparity between whites and Hispanics narrows down during these five years. Hispanics are no longer significantly lower than whites, regarding accumulation of home equity. Asians enlarge their advantage over whites on realizing equity from their homes. Changes in racial differences in home equity from 2001 to 2005 indicate that Asians and Hispanics reap the benefit of the boom in real estate market but Blacks do not.

Being older and having more young children at home are positively associated with the amount of home equity. An additional year in age will increase home equity by $\$ 1300$ in 2001 and by $\$ 1900$ in 2005 . The accruement of home equity associated with one more child at home is $\$ 3,300$ in 2001 and $\$ 10,100$ in 2005 . Marital status in both years and the gender of the householder in 2001 do not have significant effects on home equity. Persons in male headed households, on average, have $\$ 7,900$ less in home equity than those in female headed households.

Income and college education are positively correlated to home equity. Every $1 \%$ increase in household income (in $\$ 10,000)$ increases home equity by $\$ 229$ in 2001 and by $\$ 331$ in 2005 . Persons with a college degree accumulate about $\$ 30,000$ more in home equity than do those with no high school diploma. The positive impact of having postgraduate education jumps to $\$ 48,700$ in 2001 and $\$ 55,200$ in 2005 . The positive effects of family needs (e.g., the number of young children at home) and socioeconomic status on home equity lend support to the assimilation model's micro-economics perspective. Compared to natives, naturalized citizens accrue more home equity and non-citizens do not show a significant difference. The coefficients for naturalization are $\$ 9,900$ and $\$ 30,200$ in 2001 and 2005 respectively.

With comparison to those living in the Northeast, people in the Midwest and in the South have less home equity

${ }^{6}$ Significance of the difference between two groups' coefficients in a year is by a t-test in this part (6.4).

$$
t^{*}=\frac{b_{1}-b_{2}}{\sqrt{S E_{1}^{2}+S E_{2}^{2}}}
$$


whereas people in the West show an advantage in home equity. Home equity in the Midwest is, on average, worth $\$ 30,000$ less in 2001 and $\$ 66,000$ less in 2005 . Living in the South is associated with a disadvantage in home equity of $\$ 30,000$ in 2001 and $\$ 43,400$ in 2005 . Living in the West has an advantage in home equity of $\$ 37,500$ in 2001 and $\$ 84,300$ in 2005 . The differences in home equity by regions may reflect the regional differences in housing values. Living in suburbs is positively related to home equity while living in exurbs is negatively to home equity (central cities are the reference group). Living in suburbs increases home equity by \$7,900 in 2001 and $\$ 13,500$ in 2005 while living in exurbs depresses home equity by $\$ 16,600$ in 2001 and $\$ 34,600$ in 2005.

Previously owning another home, paying a down payment and years of residence all have positive effects on home equity. Interest rates, using an adjustable rate mortgage (ARM) or a government backed mortgage (FHA/VA/FHAM) are negatively associated with home equity. Condominium owners do not significantly differ in home equity from owners of other types of housing units. Home equity of prior owners is, on average, $\$ 21,400$ (in 2001) and $\$ 35,100$ (in 2005 ) more than that of first time home owners. Paying a down payment increases home equity by $\$ 15,200$ in 2001 and $\$ 38,000$ in 2005. Every additional year of residence associates with an increase in home equity of $\$ 800$ in 2001 and $\$ 2,200$ in 2005 . When mortgage interest rates increase by one percent, home equity will on average decrease by $\$ 15,200$ in 2001 and $\$ 38,000$ in 2005. Home owners who use an ARM accrue $\$ 8,500$ less in home equity do those who use fixed rate mortgages (in 2001). Using an ARM does not show any significant impact on home equity in 2005. The average net equity of home owners who use government backed mortgages, including FHA, VA and FHAM, is more than $\$ 30,000$ lower than that of home owners who do not use these government programs.

Table 2. General OLS Regression Models of Home Equity

\begin{tabular}{|c|c|c|c|c|}
\hline \multirow[t]{3}{*}{ (n) } & \multicolumn{2}{|c|}{2001} & \multicolumn{2}{|c|}{2005} \\
\hline & $\mathrm{b}$ & SE & $\mathrm{b}$ & SE \\
\hline & -1.76 & 0.9414 & $-3.13^{*}$ & 1.5207 \\
\hline \multicolumn{5}{|l|}{ Race } \\
\hline Black & -0.68 & 0.3630 & $-1.48 *$ & 0.6448 \\
\hline Asian & $1.84 *$ & 0.6360 & $2.30 *$ & 1.0750 \\
\hline Hispanic & $-1.67 *$ & 0.4280 & -0.85 & 0.7055 \\
\hline \multicolumn{5}{|c|}{ Household Composition Characteristics } \\
\hline Married & 0.13 & 0.2358 & 0.03 & 0.4006 \\
\hline Male Householder & -0.24 & 0.2095 & $-0.79 *$ & 0.3491 \\
\hline Age & $0.13 *$ & 0.0102 & $0.19 *$ & 0.0173 \\
\hline Number of Children & $0.33 *$ & 0.0914 & $1.01 *$ & 0.1601 \\
\hline \multicolumn{5}{|l|}{ Socioeconomic Status } \\
\hline Income & $2.29 *$ & 0.1098 & $3.31 *$ & 0.1981 \\
\hline High School & 0.17 & 0.4269 & -0.92 & 0.7849 \\
\hline Some College & 0.61 & 0.4145 & -0.54 & 0.7635 \\
\hline College Degree & $3.03 *$ & 0.4319 & $3.15^{*}$ & 0.7922 \\
\hline Postgraduate & $4.87 *$ & 0.4530 & $5.52 *$ & 0.8271 \\
\hline \multicolumn{5}{|l|}{ Citizenship } \\
\hline Naturalized Citizen & $0.99 *$ & 0.4849 & $3.02 *$ & 0.8185 \\
\hline Non-Citizen & 0.18 & 0.6344 & -0.17 & 1.0225 \\
\hline \multicolumn{5}{|c|}{ Geographic Characteristics } \\
\hline Midwest & $-3.01 *$ & 0.2827 & $-6.60 *$ & 0.4976 \\
\hline South & $-2.95 *$ & 0.2732 & $-4.34 *$ & 0.4810 \\
\hline West & $3.75 *$ & 0.2969 & $8.43 *$ & 0.5195 \\
\hline Suburb & $0.79 *$ & 0.2299 & $1.35^{*}$ & 0.4030 \\
\hline Exurb & $-1.66^{*}$ & 0.2000 & $-3.46^{*}$ & 0.5008 \\
\hline \multicolumn{5}{|l|}{ Financial Characteristics } \\
\hline Prior Owner & $2.14 *$ & 0.2134 & $3.51 *$ & 0.3751 \\
\hline Down Payment & $1.52 *$ & 0.3891 & $3.80 *$ & 0.6094 \\
\hline Interest Rate & $-0.46^{*}$ & 0.0695 & $-1.12 *$ & 0.1161 \\
\hline ARM Mortgage & $-0.85 *$ & 0.2783 & -0.33 & 0.4877 \\
\hline FHA/VA/FHAM & $-3.29 *$ & 0.2363 & $-3.03 *$ & 0.4573 \\
\hline \multicolumn{5}{|l|}{ Other Factors } \\
\hline Length of Residence & $0.08 *$ & 0.0126 & $0.22 *$ & 0.0215 \\
\hline Condominium Owner & -0.69 & 0.4280 & -0.83 & 0.7214 \\
\hline $\mathrm{N}$ & 15456 & & 16515 & \\
\hline $\mathrm{R}^{2}$ & 0.21 & & 0.19 & \\
\hline
\end{tabular}




\subsection{Racial Group-Specific OLS Regression Models of Home Equity}

OLS models of home equity are analyzed for each racial group separately to evaluate the differences in the effects of these predictors on home equity across racial groups. Some predictors show uniform patterns of their effects on home equity for all groups. In 2001, for Asians, none of the four household composition characteristics has an effect on home equity. An additional year in age is associated with an increase in home equity of whites, Blacks and Hispanics by $\$ 1,300, \$ 600$ and $\$ 700$ respectively. The increase in home equity of whites is larger than that of Blacks. With one more child at home, home equity of whites increases by $\$ 3,700$ whereas that of other groups does not change.

Every $1 \%$ increase in household income (in $\$ 10,000$ ) is associated with increases in home equity of whites, Blacks, Asians and Hispanics by $\$ 254, \$ 84, \$ 293$ and $\$ 84$ respectively, independent of other variables. Whites and Asians achieve higher returns to income than do Blacks and Hispanics. White owners who have at least some college attain more home equity than do whites with no high school diploma. The advantage of educational achievement increases with the levels of attainment. The coefficients of some college education, a college degree and postgraduate education are $\$ 11,800, \$ 35,800$ and $\$ 55,000$ respectively. Postgraduate education has a positive effect on the home equity of Blacks and Hispanics, compared to their coethnics who have no high school diploma. The corresponding increase in home equity is $\$ 26,300$ for Blacks and \$54,600 for Hispanics. Education appears to exert no impact on Asians' home equity.

Regarding citizenship status, native born Americans and non-citizens do not differ in home equity. Naturalized white and Black citizens realize higher equity from their housing units than do their native born coethnics. The coefficients of these two groups are similar to each other, $\$ 26,300$ for whites and $\$ 24,600$ for Blacks. Citizenship status fails to make any internal group difference in home equity among Asian and Hispanic owners.

White and Black home owners share a similar pattern of variation in home equity by regions. In comparison to the Northeast, living in the Midwest and in the South depresses home equity while living in the West is correlated with an increase in home equity. Asians in the South accumulate less home equity $(\$ 65,500)$ than do those in the Northeast. Home equity among Asians in the West is about $\$ 60,000$ higher than in the Northeast. Hispanics in the Northeast, the Midwest and the South do not significantly differ in home equity while those in the West accrue $\$ 28,100$ more in home equity. Except for whites, living in central cities, suburbs or exurbs does not impact home equity.

All financial characteristics exert significant impacts on white owners' home equity. Whites who previously owned a home, on average, accumulate $\$ 23,400$ more in equity than first time buyers. Paying a down payment is associated with an increase in home equity of $\$ 14,500$ among whites. With one percentage point increase in mortgage interest rates, white owners' equity decreases by $\$ 5,400$. White owners who use an ARM or a government backed mortgage (FHA/VA/FHAM) accumulate $\$ 11,500$ and $\$ 36,200$ less in home equity respectively than those who use fixed rate mortgages or non-government backed mortgages.

In contrast, only one or two of these financial factors influence the home equity of minority groups. Blacks using a government backed mortgage, on average, realize $\$ 17,800$ less in home equity, compared to those who do not use these programs. Asian prior owners have a $\$ 39,300$ advantage in home equity over first time owners. For Hispanics, paying down a payment is associated with an increase in home equity of $\$ 25,900$ while using a government backed mortgage decreases home equity by $\$ 24,600$. The decline in home equity associated with using a government backed mortgage is more substantial for whites than for Blacks.

An additional year of residence in the current housing unit increases the home equity of whites, Asians and Hispanics by $\$ 900, \$ 3,500$ and $\$ 1,000$ respectively. Only Asians show a notable internal difference in home equity, with respect to condominium ownership. Asian condominium owners, on average, accrue $\$ 85,900$ less in home equity than their coethnics owning other types of housing units. 
Table 3. Group-Specific OLS Regression Models of Home Equity

\begin{tabular}{|c|c|c|c|c|c|c|c|c|}
\hline \multirow[t]{2}{*}{2001} & \multicolumn{2}{|c|}{ White } & \multicolumn{2}{|c|}{ Black } & \multicolumn{2}{|c|}{ Asian } & \multicolumn{2}{|c|}{ Hispanic } \\
\hline & $\mathrm{b}$ & SE & $\mathrm{b}$ & SE & $\mathrm{b}$ & SE & $\mathrm{b}$ & SE \\
\hline Intercept & $-2.33^{*}$ & 1.1279 & $4.21 *$ & 2.1259 & -6.09 & 8.2637 & -1.69 & 2.7497 \\
\hline \multicolumn{9}{|c|}{ Household Composition Characteristics } \\
\hline Married & 0.14 & 0.2714 & 0.79 & 0.5689 & 0.89 & 2.0353 & -0.39 & 0.7211 \\
\hline Male- Headed & -0.33 & 0.2382 & -0.83 & 0.5370 & 0.40 & 1.7233 & 0.98 & 0.6800 \\
\hline Age & $0.13 *$ & 0.0117 & $0.06^{*}$ & 0.0265 & 0.09 & 0.0834 & $0.07 *$ & 0.0311 \\
\hline Number of Children & $0.37 *$ & 0.1070 & 0.08 & 0.2244 & -0.02 & 0.6931 & -0.14 & 0.2496 \\
\hline \multicolumn{9}{|l|}{ Socioeconomic Status } \\
\hline Income & $2.54 *$ & 0.1241 & $0.84 *$ & 0.2814 & $2.93^{*}$ & 0.9164 & $0.84 *$ & 0.3726 \\
\hline High School & 0.73 & 0.5701 & -1.20 & 0.8644 & -1.55 & 3.5139 & -0.67 & 0.8815 \\
\hline Some College & $1.18^{*}$ & 0.5568 & -0.94 & 0.8523 & -0.50 & 3.2608 & 0.83 & 0.8694 \\
\hline College Degree & $3.58^{*}$ & 0.5714 & 1.48 & 0.9603 & 2.42 & 3.0472 & 0.91 & 1.0429 \\
\hline Postgraduate & $5.50^{*}$ & 0.5892 & $2.63^{*}$ & 1.0444 & 1.31 & 3.2227 & $5.46^{*}$ & 1.4060 \\
\hline \multicolumn{9}{|l|}{ Immigration } \\
\hline Naturalized & $2.63^{*}$ & 0.8205 & $2.46^{*}$ & 1.2054 & -2.48 & 1.7584 & 0.47 & 0.7393 \\
\hline Non-Citizen & 0.23 & 1.2017 & -0.95 & 1.7036 & -1.76 & 2.3824 & -0.41 & 0.8781 \\
\hline \multicolumn{9}{|c|}{ Geographic Characteristics } \\
\hline Midwest & $-3.04 *$ & 0.3092 & $-3.78 *$ & 0.8494 & -3.84 & 2.7665 & -1.59 & 1.3452 \\
\hline South & $-3.07 *$ & 0.3068 & $-3.14 *$ & 0.7341 & $-6.55^{*}$ & 2.4637 & -1.23 & 1.0619 \\
\hline West & $3.64 *$ & 0.3358 & $4.89 *$ & 1.0015 & $5.96^{*}$ & 2.0596 & $2.81^{*}$ & 1.0592 \\
\hline Suburb & $0.82 *$ & 0.2741 & 0.20 & 0.5341 & 2.74 & 1.5566 & 0.81 & 0.6324 \\
\hline Exurb & $-1.65^{*}$ & 0.3350 & -0.16 & 0.8837 & 1.88 & 5.2932 & -1.08 & 1.2587 \\
\hline \multicolumn{9}{|c|}{ Financial Characteristics } \\
\hline Prior Owner & $2.34 *$ & 0.2451 & 0.77 & 0.5525 & $3.93^{*}$ & 1.5876 & 0.32 & 0.6737 \\
\hline Down Payment & $1.45^{*}$ & 0.4468 & 0.83 & 0.8422 & 4.87 & 4.0403 & $2.59 *$ & 1.3423 \\
\hline Interest Rate & $-0.54 *$ & 0.0840 & -0.23 & 0.1303 & 0.01 & 0.7172 & -0.07 & 0.1917 \\
\hline ARM Mortgage & $-1.15^{*}$ & 0.3100 & 1.17 & 0.6413 & -0.59 & 2.4568 & 0.05 & 0.8773 \\
\hline FHA/VA/FHAM & $-3.62 *$ & 0.2781 & $-1.78^{*}$ & 0.5082 & -4.09 & 2.2081 & $-2.46^{*}$ & 0.6552 \\
\hline \multicolumn{9}{|l|}{ Other Factors } \\
\hline Years of Residence & $0.09 *$ & 0.0141 & 0.02 & 0.0301 & $0.35^{*}$ & 0.1357 & $0.10^{*}$ & 0.0448 \\
\hline \multicolumn{9}{|l|}{ Condominium } \\
\hline Owner & -0.14 & 0.4966 & -1.04 & 1.3173 & $-8.59 *$ & 2.4879 & -1.90 & 1.1936 \\
\hline $\mathrm{N}$ & 12413 & & 1222 & & 444 & & 1017 & \\
\hline $\mathrm{R}^{2}$ & 0.21 & & 0.17 & & 0.25 & & 0.13 & \\
\hline
\end{tabular}

${ }^{*} p($ probability $>|t|)<0.05$ 
Table 3. Group-Specific OLS Regression Models of Home Equity (continued)

\begin{tabular}{|c|c|c|c|c|c|c|c|c|}
\hline \multirow[t]{2}{*}{2005} & \multicolumn{2}{|c|}{ White } & \multicolumn{2}{|c|}{ Black } & \multicolumn{2}{|c|}{ Asian } & \multicolumn{2}{|c|}{ Hispanic } \\
\hline & $\mathrm{b}$ & $\mathrm{SE}$ & $\mathrm{b}$ & SE & $\mathrm{b}$ & SE & $\mathrm{b}$ & SE \\
\hline Intercept & $-3.91 *$ & 1.8639 & 4.69 & 3.0956 & -5.87 & 13.516 & -5.89 & 4.6446 \\
\hline \multicolumn{9}{|c|}{ Household Composition Characteristics } \\
\hline Married & 0.22 & 0.4680 & -0.40 & 0.8748 & 0.69 & 3.4585 & -0.10 & 1.2866 \\
\hline Male Householder & $-0.89 *$ & 0.4030 & 0.50 & 0.7977 & -1.15 & 2.8057 & -1.48 & 1.1689 \\
\hline Age & $0.21 *$ & 0.0203 & $0.08^{*}$ & 0.0395 & 0.17 & 0.1449 & $0.14^{*}$ & 0.0565 \\
\hline Number of Children & $1.28 *$ & 0.1898 & -0.23 & 0.3413 & 0.62 & 1.2285 & 0.49 & 0.4666 \\
\hline \multicolumn{9}{|l|}{ Socioeconomic Status } \\
\hline Income & $3.58^{*}$ & 0.2327 & 0.71 & 0.4428 & $2.40 *$ & 1.0468 & $3.62 *$ & 0.7457 \\
\hline High School & -0.65 & 1.0972 & -0.93 & 1.3899 & -2.42 & 6.9103 & -0.82 & 1.5627 \\
\hline Some College & -0.03 & 1.0691 & -0.05 & 1.3414 & 2.44 & 6.64 & -2.73 & 1.6148 \\
\hline College Degree & $3.75^{*}$ & 1.0931 & 1.76 & 1.5045 & 5.37 & 6.3411 & -0.77 & 1.8862 \\
\hline Postgraduate & $5.90^{*}$ & 1.1227 & $7.29 *$ & 1.6393 & 5.14 & 6.4036 & $7.50 *$ & 2.4225 \\
\hline \multicolumn{9}{|l|}{ Citizenship } \\
\hline Naturalized & $6.73 *$ & 1.3647 & -1.00 & 1.5722 & -1.11 & 3.0085 & 1.77 & 1.3639 \\
\hline Non-Citizen & 0.17 & 2.0427 & -0.62 & 2.4264 & -3.50 & 3.9539 & -0.12 & 1.4792 \\
\hline \multicolumn{9}{|c|}{ Geographic Characteristics } \\
\hline Midwest & $-6.62 *$ & 0.5526 & $-7.32 *$ & 1.3205 & -7.02 & 4.3540 & -4.21 & 2.3514 \\
\hline South & $-4.50 *$ & 0.5494 & $-4.88^{*}$ & 1.1418 & -6.03 & 3.9029 & -3.51 & 1.8817 \\
\hline West & $8.38 *$ & 0.5998 & $6.42 *$ & 1.6367 & $13.74 *$ & 3.4294 & $7.47 *$ & 1.8534 \\
\hline Suburb & $1.06^{*}$ & 0.4913 & $1.72 *$ & 0.8191 & 0.17 & 2.6958 & $2.93 *$ & 1.1475 \\
\hline Exurb & $-3.90 *$ & 0.5819 & -1.34 & 1.2015 & 2.14 & 5.8546 & -2.33 & 1.9360 \\
\hline \multicolumn{9}{|c|}{ Financial Characteristics } \\
\hline Prior Owner & $3.45^{*}$ & 0.4417 & $1.94 *$ & 0.8461 & $8.53^{*}$ & 2.5559 & 1.84 & 1.1662 \\
\hline Down Payment & $3.50 *$ & 0.7159 & 1.36 & 1.2338 & $14.10^{*}$ & 7.2274 & $6.79 *$ & 1.9341 \\
\hline Interest Rate & $-1.26^{*}$ & 0.1411 & -0.27 & 0.1934 & $-2.62 *$ & 1.1289 & $-0.72 *$ & 0.3613 \\
\hline ARM Mortgage & -0.60 & 0.5692 & -0.58 & 1.049 & 3.79 & 3.7281 & 1.67 & 1.6203 \\
\hline FHA/VA/FHAM & $-3.39 *$ & 0.5502 & -1.57 & 0.8219 & -0.53 & 4.5445 & $-3.15^{*}$ & 1.3349 \\
\hline \multicolumn{9}{|l|}{ Other Factors } \\
\hline Years of Residence & $0.22 *$ & 0.0247 & 0.06 & 0.0458 & $0.80^{*}$ & 0.2217 & $0.26^{*}$ & 0.0808 \\
\hline \multicolumn{9}{|l|}{ Condominium } \\
\hline Owner & -0.50 & 0.8566 & 0.05 & 1.8442 & $-8.37 *$ & 4.1704 & 0.17 & 2.1076 \\
\hline $\mathrm{N}$ & 12960 & & 1243 & & 515 & & 1278 & \\
\hline $\mathrm{R}^{2}$ & 0.19 & & 0.16 & & 0.25 & & 0.19 & \\
\hline
\end{tabular}

$* p($ probability $>|t|)<0.05$

Most of the significant predictors in both years are larger in magnitude in 2005 than in 2001. In 2005, age continues to be positively associated with home equity and this effect is larger for whites than for Blacks. The number of children has a positive effect only on whites' home equity, the same as in 2001. Only whites show a gender difference in home equity. White owners who have a female household head have, on average, more home equity than their counterparts having a male householder (the widow effect).

Income exerts no more significant impact on Blacks' home equity. Whites and Hispanics attain similar returns of home equity to their income and both are higher in 2005 than in 2001. Asians experience a slight decrease in their return of home equity to income. Every $1 \%$ increase in household income (in $\$ 10,000$ ) increases the home equity of whites, Asians and Hispanics by $\$ 358, \$ 240$ and $\$ 362$ respectively. Whites no longer achieve a higher return of home equity to income than Hispanics in 2005. The return of home equity to income for whites is not significantly different from that for Hispanics. Income fails to have a significant effect on home equity of Blacks. 
Whites with a college or above degree show an advantage on accruement of home equity over their coethnics who did not have a high school diploma. This advantage also increases in 2005, compared to 2001. The increase in home equity associated a college degree and postgraduate education is $\$ 37,500$ and $\$ 59,000$ respectively. For Blacks and Hispanics, the gap between those with no high school diploma and those receiving postgraduate education also widens in 2005 . The advantage of postgraduate education is above $\$ 70,000$ for both groups. Education continues to have no effect on Asians' home equity.

None of three minority groups is characterized by variation in home equity according to their citizen status. White naturalized citizens, however, accumulate $\$ 67,300$ more in home equity than their native born coethnics. White native born Americans and non-citizens do not notably differ in home equity. The disparity of home equity between white native born Americans and their naturalized coethnics is larger in 2005 than 2001.

Similar to 2001, all regional dummy variables continue to exert significant impacts on the home equity of white and Black home owners in 2005. Only Asians and Hispanics in the West significantly differ in home equity from their coethnics in the Northeast. These predictors increase their effects in 2005. When living in the Northeast is used as the reference group, whites in the Midwest and the South attain \$66,200 and \$45,000 less in home equity while whites in the West accumulate $\$ 83,800$ more in home equity. The coefficients associated with Blacks in the Midwest, the South and the West are negative $\$ 73,200$, negative $\$ 48,800$ and $\$ 64,200$ respectively. The advantage of living in the West over the Northeast on the accumulation of home equity is $\$ 137,400$ for Asians and $\$ 74,700$ for Hispanics. The increases in the predictor variables' effects reflect a larger increase in housing values and then home equity in the Northeast and the West than that in the Midwest and the South.

The effects of living in suburbs and exurbs on whites' home equity, compared to central cities, are still significant in 2005. The absolute values of these coefficients are larger in 2005 than in 2001. Compared to central cities, living in suburbs is associated with an increase in whites' home equity of $\$ 10,600$ and living in exurbs is associated with a decrease in home equity of $\$ 39,000$. Living in suburbs also increases Blacks' and Hispanics' home equity. The coefficients for Blacks and Hispanics are $\$ 17,200$ and $\$ 29,300$ respectively. Unlike in 2001, Blacks and Hispanics benefit from suburban residence in 2005. The equity of Asians has no association with these dummy variables.

Whites who previously owned a house, and who paid a down payment benefit in terms of home equity. Mortgage interest rates and using government backed mortgages (FHA/VA/FHAM) have negative correlations to home equity of white owners. Unlike 2001, using an ARM no longer significantly affects whites' home equity in 2005. Whites who previously owned a house accumulate $\$ 34,500$ more in home equity than white first time owners. The increase in whites' home equity associated with paying a down payment is $\$ 35,000$. When mortgage interest rates increase by one percent point, whites' home equity decreases by $\$ 12,600$. Compared to whites who do not use government backed mortgages, whites using these programs show a disadvantage in home equity of $\$ 33,900$.

Black prior owners show an advantage in the accumulation of home equity over their first time owner coethnics by $\$ 19,400$. The increases in Asians' home equity associated with being a prior owner and paying a down payment are $\$ 85,300$ and $\$ 1,410,000$ in 2005 . Every one percent increase in mortgage interest rates associates with a decrease of $\$ 26,200$ in Asians' home equity. Owning another home previously is the only financial factor to affect Asians' home equity in 2001. Paying a down payment increases Hispanics' home equity by $\$ 67,900$ while using government backed mortgages depresses their home equity by $\$ 31,500$, compared to those who do not use these programs. Mortgage interest rates only impact Hispanics' home equity in 2005. Every one percent increase in mortgage interest rates is associated with a decrease of $\$ 7,200$ in home equity. Across all populations, those predictors that are significant in both years tend to be larger in 2005 than in 2001.

Years of residence positively associate with home equity for whites, Asians and Hispanics. With an additional year living in the current housing unit, the increases in home equity for whites, Asians and Hispanics are $\$ 2,200, \$ 8,000$ and $\$ 2,600$. This positive effect of length of residence is larger in 2005 than in 2001 . The amount of home equity increased with one additional year of residence for Asians is larger than that for whites and Hispanics. Asians again are the only group to show a difference in home equity between condominium owners and owners of other types of housing units. The decrease in home equity associated with condominium ownership is $\$ 83,700$ in 2005, similar to 2001 .

\section{Conclusion}

This paper analyzes ethnic disparities in home equity by using national samples from the 2001 and 2005 American Housing Survey. The 2001 and 2005 AHS data allow cross-time comparisons of racial housing inequality in the United States. General and group-specific models are estimated for each year. This study draws inspiration from two main broad theoretical approaches of housing inequality, the assimilation and stratification perspectives. Both perspectives receive some support from the findings. 
The assimilation perspective is supported by some of the findings reported above. In accordance with this perspective, group differences in home equity can be attributed to differences in compositional variables, such as life course and household composition characteristics and socioeconomic status. In the general models, some household composition and socioeconomic factors are found to be significantly associated with home equity. People who are older, have more young children at home, earn more income and have at least a college degree (in comparison to those with no high school diploma) are predicted to accrue more home equity in both years. In the group-specific models, some individual level predictor variables show uniform patterns of their effects on home equity across racial groups. The positive effects of age, income and postgraduate education on home equity are consistent with the assimilation perspective. The stratification perspective also receives some support. In the general models, Hispanics accumulate less home equity than whites in 2001 and Blacks are worse off than whites in 2005. In the group-specific models, some predictor variables' effects show racially stratified patterns. In both years, only whites' home equity increases with an increase in the number of young children at home, an indicator of family needs. With an additional year of age, the increase in home equity is larger for whites than for Blacks. Whites, moreover, achieve a higher return to home equity from their income than is the case for Blacks. The returns of home equity to income for whites and Asians are higher than those for Blacks and Hispanics in 2001. There is no significant return for Blacks in 2005. Only whites experience a significant effect of a college degree on home equity in both years. Asians do not receive any significant return to their educational achievement. These patterns support the stratification perspective.

The effects of the predictor variables appear to show some change over time. The absolute value of most significant predictor variables' coefficients increases from 2001 to 2005 in both the general and the group-specific models. The effects of age, income and postgraduate education are more substantial in 2005 than in 2001. By contrast, Asians' return of equity to income slightly declines and Blacks' return diminishes to be insignificant. Other significant predictor variables, such as regions, locations and most of the financial factors also stand out with more striking effects in 2005 than in 2001. This increasing trend indicates that the effects of the predictor variables may be exaggerated due to increases in housing values and home equity during the housing boom.

Hispanics successfully eliminated their net disadvantage over whites in home equity accumulation during this spell. The net gap between Asians and whites is amplified. In addition, there is no significant inter-group difference among whites, Asians and Hispanics, regarding their returns of home equity to income in 2005. These changes indicate that Asians and Hispanics reaped the benefit of the housing boom. Blacks, however, do not benefit from this boom. There is no net racial disparity of home equity between whites and Blacks in 2001; while Blacks show a significant disadvantage over whites in 2005. The return of home equity to income for Blacks is lower than for whites in both years.

\section{Acknowledgements}

We would like to express our appreciation to Professor Jimy Sanders at the University of South Carolina who guided us through this research and provided us help for proof reading.

\section{References}

Alba, R. D., \& Logan, J. R. (1991). Variations on Two Themes: Racial and Ethnic Patterns in the Attainment of Suburban Residence. Demography, 28, 431-453. http://dx.doi.org/10.2307/2061466

Alba, R. D., \& Logan, J. R. (1992). Assimilation and Stratification in the Homeownership Patterns of Racial and Ethnic Groups. International Migration Review, 26, 1314-1341. http://dx.doi.org/10.2307/2546885

Alba, R. D., Logan, J. R., Stults, B. J., Marzan, G., \& Zhang, W. (1999). Immigrant Groups in the suburbs: A Reexamination of Suburbanization and Spatial Assimilation. American Sociological Review, 64, 446-460. http://dx.doi.org/10.2307/2657495

Alba, R.D., Logan, J.R., \& Stults, B.J. (2000). The Changing Neighborhood Contexts of the Immigrant Metropolis. Social Forces, 79, 587-621. http://dx.doi.org/10.2307/2675510

Avery, R. B., Brevoort, K. P., \& Canner, G. B. (2008). The 2007 HMDA Data. Federal Reserve Bulletin, 94, 107-146.

Been, V., Ellen, I., \& Madar, J. (2009). The High Cost of Segregation: Exploring Racial Disparities in High-Cost Lending. Fordham Urban Law Journal, 36, 361-393.

Bond, C., \& Williams, R. (2007). Residential Segregation and the Transformation of Home Mortgage Lending. Social Forces, 86, 671-698. http://dx.doi.org/10.1093/sf/86.2.671

Charles, C. Z. (2001). Processes of Racial Residential Segregation. In A.O'Connor, C. Tilly, and L. D. Bobo (Eds.), Urban Inequality (pp. 217-271). New York: Russell Sage Foundation.

Conley, D. (1999). Being Black, Living in the Red: Race, Wealth, and Social Policy in America. Berkeley, CA: 
University of California Press.

Emerson, M. O., Chai, K. J., \& Yancey, G. (2001). Does Race Matter in Residential Segregation? Exploring the Preferences of White Americans. American Sociological Review, 66, 922-935 http://dx.doi.org/10.2307/3088879

Farley, R. (1996). Racial Differences in the Search for Housing: Do Whites and Blacks Use the Same Technique to Find Housing? Housing Policy Debate, 7, 367-385. http://dx.doi.org/10.1080/10511482.1996.9521225

Flippen, C. (2001a). Racial and Ethnic Inequality in Homeownership and Housing Equity. Sociological Quarterly, 42, 121-149. http://dx.doi.org/10.1111/j.1533-8525.2001.tb00028.x

Flippen, C. (2001b). Residential Segregation and Minority Homeownership. Social Science Research, 30, 337-362. http://dx.doi.org/10.1006/ssre.2001.0701

Flippen, C. (2004). Unequal Returns to Housing Investments? A study of Real Housing Appreciation among Black, White, and Hispanic Households. Social Forces, 82, 1523-1551. http://dx.doi.org/10.1353/sof.2004.0069

Holloway, S., \& Wyly, E. (2001). The Color of Money's Expanded: Geographically Contingent Mortgage Lending in Atlanta. Journal of Housing Research, 12, 55-90.

Krivo, L. J. (1986). Home Ownership Differences between Hispanics and Anglos in the United States. Social Problems, 33, 319-333. http://dx.doi.org/10.2307/800722

Krivo, L. J., \& Kaufman. R. L. (2004). Housing and Wealth Inequality: Racial-Ethnic Differences in Home Equity in the United States. Demography, 41(3), 585-605. http://dx.doi.org/10.1353/dem.2004.0023

Logan, J. R., Alba, R. D., McNulty, T., \& Fisher, B. (1996). Making a Place in the Metropolis: Locational Attainment in Cities and Suburbs. Demography, 33, 443-453.

Logan, J. R., Alba, R. D., \& Zhang, W. (2002). Immigrant Enclaves and. Ethnic Communities in New York and Los Angeles. American Sociological Review, 67, 299-322. http://dx.doi.org/10.2307/3088897

Logan, J. R., Stults, B., \& Farley, R. (2004). Segregation of Minorities in the Metropolis: Two Decades of Change. Demography, 41, 1-22. http://dx.doi.org/10.1353/dem.2004.0007

Massey, D. (1985). Ethnic Residential Segregation: A Theoretical Synthesis and Empirical Review. Sociology and Social Research, 69, 315-350.

Massey, D., \& Denton, N. (1992a). Racial Identity and the Spatial Assimilation of Mexicans in the United States. Social Science Research, 21, 235-260. http://dx.doi.org/10.1016/0049-089X(92)90007-4

Massey, D., \& Denton, N. (1992b). Residential Segregation of Asian Origin Groups in U.S. Metropolitan Areas. Sociology and Social Research, 76, 170-177.

Massey, D., \& Denton, N. (1993). American Apartheid: Segregation and the Making of the Underclass.

Cambridge, MA: Harvard University Press. http://dx.doi.org/10.1086/229532

Megbolugbe, I. \& Cho, M. (1996). Racial and Ethnic Differences in Housing Demand: An Econometric Investigation. Journal of Real Estate Finance and Economics, 12, 295-318.

http://dx.doi.org/10.1007/BF00127539

Myers, S. \& Chan, T. (1995). Racial Discrimination in Housing Markets: Accounting for Credit Risk. Social Science Quarterly, 76, 543-561.

Oliver, M. L. \& Shapiro, T. M. (1995). Black Wealth / White Wealth. New York \& London: Routledge.

Rosenbaum, E. (1996). Racial/Ethnic Differences in Home Ownership and Housing Quality, 1991. Social Problems, 43, 403-426.

Rosenbaum, E. \& Friedman, E. (2001). Differences in the Locational Attainment of Immigrant and Native-Born Households with Children in New York City. Demography, 38, 337-348.

http://dx.doi.org/10.1353/dem.2001.0030

Ross, S. \& Yinger, J. (2002). The Color of Credit: Mortgage Discrimination, Research Methodology and Fair-Lending Enforcement. Cambridge, MA: MIT Press.

Rugh, J., \& Massey, D. (2010). Residential Segregation and the American Foreclosure Crisis. American Sociological Review, 75, 629-651. http://dx.doi.org /10.1177/0003122410380868 
Shapiro, T. M. (2004). The hidden Cost of Being African American: How Wealth Perpetuates Inequality. Oxford: University press.

South, S., Crowder, K., \& Chavez., E. (2005). Migration and Spatial Assimilation among U.S. Latinos: Classical versus Segmented Trajectories. Demography, 42, 497-521. http://dx.doi.org/10.1353/dem.2005.0025

Stuart, G. (2003). Discrimination Risk: The U.S. Mortgage Lending Industry in the Twentieth Century. Ithaca, NY: Cornell University Press.

Turner, M. (1992). Discrimination in Urban Housing Markets: Lessons from Fair Housing Audits. Housing Policy Debate, 3, 185-215.

Williams, R., Nesiba, R., \& McConnell, E. D. (2005). The Changing Face of Inequality in Home Mortgage Lending. Social Problems, 52, 181-208. http://dx.doi.org/10.1525/sp.2005.52.2.181

Wilson, F. D. \& Hammer, R. B. (2001). Ethnic Residential Segregation and Its Consequences. In A. O'Connor, C. Tilly, and L. D. Bobo (Eds.), Urban Inequality (pp. 272-303). New York: Russell Sage Foundation.

Yinger, J. (1995). Closed Doors, Opportunities Lost: the Continuing Costs of Housing Discrimination. New York: Russell Sage Foundation.

\section{Appendix}

Variable

Operationalization

Dependent Variable

Home Equity

Predictor Variables

Race

White

Dummy variable coded 1 if the householder or spouse is white.

Black

Dummy variable coded 1 if the unmarried householder is Black or the householder or spouse is Black and none is white.

Asian

Dummy variable coded 1 if the unmarried householder is Asian or both the householder and spouse are Asian.

Hispanic

Dummy variable coded 1 if the unmarried householder is Hispanic or the householder or spouse is Hispanic and none is white or Black.

Household Composition Characteristics

Age

Male Householder

Married

Number of Children

Socioeconomic Status

Household Income

Education

Assimilation

Native-Born Citizen

Naturalized Citizen

Non-Citizen
The maximum of the householder's or spouse's age.

Dummy variable coded 1 if the householder is male.

Dummy variable coded 1 if the householder is married.

The number of children in the household under 18 .

Household yearly income $(\$ 10,000)$.

The maximum of the householder's or spouse's educational achievement in dummy variables for less than high school, high school, some college, college and postgraduate.

Dummy variable coded 1 if the householder or spouse is native born U.S. citizen. Dummy variable coded 1 if the householder or spouse if naturalized U.S. citizen but none is native born citizen.

Dummy variable coded 1 if neither of the householder nor spouse if a U.S. citizen. 
Appendix (continued)

\begin{tabular}{ll}
\hline Variable & Operationalization \\
\hline Geographic Characteristics & Dummy variable coded 1 if resides in the Northeast. \\
Northeast & Dummy variable coded 1 if resides in the Midwest. \\
Midwest & Dummy variable coded 1 if resides in the South. \\
South & Dummy variable coded 1 if resides in the West. \\
West & Dummy variable coded 1 if resides in a central city. \\
Central City & Dummy variable coded 1 if resides outside a central city in a metropolitan area. \\
Suburb & Dummy variable coded 1 if resides outside suburb in a metropolitan area. \\
Exurb & \\
Financial Characteristics & Dummy variable coded 1 if the householder owned house before the current one. \\
Prior Owner & Dummy variable coded 1 if the householder paid a down payment. \\
Down Payment & Primary mortgage interest rate. \\
Interest Rate & Dummy variable coded 1 if primary mortgage has variable interest rate. \\
ARM Mortgage & Dummy variable coded 1 if primary mortgage FHA/VA/FHAM mortgage. \\
FHA/VA/FHAM & The number of years the householder has lived in the current dwelling. \\
Other Factors & Dummy variables coded 1 if the housing unit is a condominium. \\
Length of Residence & Condominium Owner
\end{tabular}

\section{(cc) BY}

This work is licensed under a Creative Commons Attribution 3.0 License. 